\title{
1 A recent phase of accretion along the southern Costa Rican
}

2 subduction zone

4 Nathan L. Bangs ${ }^{1}$, K. D. McIntosh ${ }^{1}$, E. A. Silver ${ }^{2}$, J. W. Kluesner ${ }^{2}$ and César R. Ranero ${ }^{3}$

$5{ }^{1}$ Institute for Geophysics, University of Texas at Austin, PRC 196, 10100 Burnet Rd., Austin, TX

$6 \quad{ }^{2}$ Earth Sciences Department, University of California at Santa Cruz, Santa Cruz, CA

$7 \quad{ }^{3}$ Barcelona Center for Subsurface Imaging. ICREA at CSIC. ICM, Barcelona, Spain

9 Corresponding author: Nathan Bangs, nathan@ig.utexas.edu

\section{ABSTRACT}

In 2011 we acquired a 3D seismic reflection volume across the Costa Rica margin NW of

13 the Osa Peninsula to investigate the complex structure and the development of the seismogenic

14 zone within the Costa Rica subduction zone in the vicinity of recent International Ocean Drilling

15 Program (IODP) drilling. In contrast to previous interpretations, these newly acquired seismic

16 images show that the margin wedge is composed of a layered fabric that is consistent with clastic

17 sediments, similar to materials recovered from IODP drilling, that have been thrust and

18 thickened into thrust-bounded folded sequences. These structures are consistent with a balanced

19 sequence that has been frontally accreted in the context of an accretionary model. We interpret

20 these sequences as sediment originally deposited on the subducting crust in a trench basin

21 created by the southward migration of the Cocos-Nazca-Caribbean triple junction, and accreted

\section{Page 1 of 27}


22 during recent margin subduction that also accelerated with passage of the triple junction. The

23 margin is composed of relatively rapidly accreted sediment that was added to the margin during

24 a phase of accretion within the last $\sim 5 \mathrm{Ma}$ that was probably preceded throughout the Neogene

25 by periods of non-accretion or erosion.

\section{$27 \quad \mathbf{1 . 0}$ Introduction}

The Costa Rica margin is one among about half of the world's subduction zones that

29 have been interpreted to be erosive (von Huene and Scholl, 1991; Clift and Vannucchi, 2004).

30 These are convergent margins where trench sediment and upper plate material is tectonically

31 removed and carried deeper into the subduction zone and ultimately brought into the mantle. The

32 subduction erosion mechanism is globally significant because it can transport large volumes of

33 upper plate material into the seismogenic zone, affecting frictional properties and hydrogeology

34 and thus seismogenesis (von Huene, et al, 2004; Saffer and Tobin, 2011), and it can return

35 continental crust material to the mantle (von Huene, et al, 2004). von Huene and Scholl (1991)

36 estimate the volume of subducted material globally over the last 100 m.y. (1/2 to $2 / 3$ due to

37 tectonic erosion of upper plate materials), is sufficiently large to have offset the volume of

38 igneous rocks that have been added to the Earth's terrestrial crust, resulting in zero net growth of

39 Earth's continents since the Cretaceous.

40 Subduction erosion has primarily been interpreted and quantified from observation of

41 large-scale, long-term margin subsidence (e.g. Clift and Vannucchi, 2004; von Huene and

42 Scholl, 1991) and landward retreat of margins inferred from old volcanic arc rocks that formed

43100 s of $\mathrm{km}$ landward of the coast but now lie along coastal ranges or even under the continental

44 slope (e.g. Yañez et al., 2001). Subsidence is presumed to be the result of basal erosion; 
45 however, outer forearc subsidence can also be caused by changes in subduction geometry

46 following changes in plate kinematics (e.g. Regalla et al., 2013).

47 Subduction erosion is also interpreted to generate distinctive margin structures (e.g.

48 Ranero and von Huene, 2000, von Huene and Ranero, 2003); however, distinguishing erosional

49 and accretionary margins from structural observations has been surprisingly difficult, despite the

50 large difference in tectonic processes associated with subduction erosion and accretion (Ranero

51 et al. 2007). This difficulty is in part due to the inherent loss of the geologic record with tectonic

52 erosion, and structures within a margin might also be inherited from a geological process that is

53 not presently operating and structures may not be representative of current tectonics along the

54 margin. However, difficulty identifying tectonic erosion and accretion also stems from the

55 inherent uncertainties with imaging and characterizing complex deformational structures

56 associated with subduction zones.

57 The Middle America Trench convergent margin is believed to be a tectonically eroding

58 margin (Ranero and von Huene. 2000; Ranero et al., 2000; Vannucchi et al., 2003, 2004, 2013)

59 with both subsidence and structural observations supporting erosion. IODP Expedition 334

60 drilling samples from the mid slope of the Costa Rica margin NW of the Osa peninsula indicate

61 margin subsidence from near shoreline to intermediate $(800-1200 \mathrm{~m})$ water depths during the

62 last 3 m.y. of subduction history (Vannucchi, et al., 2013). Costa Rica has been interpreted as

63 one of the most aggressively eroding margins, with estimates of average rates between $100-150$

$64 \mathrm{~km}^{3} / \mathrm{m}$.y./km (compared to long-term average rates of $30 \mathrm{~km} / 3$.y./km typical of erosive margins

65 estimated by von Huene and Scholl, 1991), and with recent periods of extreme erosion estimated

66 to be as much as $1,690 \mathrm{~km}^{3} / \mathrm{m} . \mathrm{y} . / \mathrm{km}$, near the Osa Peninsula, resulting from upper plate thinning

67 due to tectonic erosion of $50-60 \mathrm{~km}$ of a preexisting forearc (Vannucchi et al., 2013). 
Structural details that reveal tectonic erosion and associated processes, however, are more

69 equivocal and have been long debated along the Costa Rica margin. Using 3D seismic images,

70 Shipley et al. (1992) argued that landward dipping structures within the frontal $\sim 20 \mathrm{~km}$ of the

71 margin wedge (the wedge shaped body of material that lies beneath the sediment cover of the

72 margin slope) offshore the Nicoya peninsula are the manifestation of thrusting and thickening of

73 material transferred from the subducting plate in an accretionary context. In contrast, von Huene

74 et al. (2000) noted that weak and discontinuous reflectivity of the margin wedge imaged in a grid

75 of 2D profiles and seafloor relief of regional swath bathymetry maps across Costa Rica and a

76 segment of Nicaragua is consistent with fractured and faulted crystalline basement and not

77 consistent with accreted sediments or out-of-sequence-thrusts typically associated with

78 accretionary wedges. They argued that the seismic structure and high seismic velocities (3.5 -

$795.5 \mathrm{~km} / \mathrm{s}$ ) of the margin wedge (Christeson et al., 1999) are more consistent with fractured

80 crystalline rocks of the Nicoya complex and that the margin wedge is crystalline basement

81 extending beneath the mid slope rather than an accretionary body. Drilling near the Osa

82 peninsula has recovered well-cemented sediments with carbonate and zeolite cements that could

83 explain the relatively high-velocity margin wedge along the $3 \mathrm{D}$ transect $(4.0-4.8 \mathrm{~km} / \mathrm{s}$;

84 Stavenhagen et al. 1998); however, the interpretation of the margin wedge remains equivocal due

85 to poor imaging of highly deformed structures.

In 2011 we acquired a 3D seismic reflection volume across an $11 \times 55 \mathrm{~km}^{2}$ area of the

87 Costa Rica margin, NW of the Osa Peninsula using the R/V Langseth to image the complex

88 deformational structures of the subduction-zone's upper plate and the geometry and reflective

89 characteristics of the subduction megathrust (Figure 1). The new 3D seismic reflection data show 
90 the complex structure of the upper-plate's margin wedge in sufficient detail that it is now clear

91 that at least the frontal 30-40 km of the margin wedge offshore Osa Peninsula has a layered

92 structure consistent with clastic sediments that have been shortened and thickened by thrust

93 faulting and folding in a fashion often seen in accretionary wedges. Consequently these

94 structures raise the question: What are the structural manifestations of an erosional margin, and

95 are they found along the southeastern Costa Rica margin, or are structures along this margin

96 more consistent with a phase of accretion? Furthermore, can the tectonic history of this margin

97 only be correctly interpreted with detail possible with high quality 3D images?

98

99 2. Structural elements of an erosive margin

100 Three key structural elements within erosive margins have been linked to erosional

101 tectonics. First, a regional unconformity at the base of the margin-slope sediment cover is

102 believed to form by gradual subsidence from near sea level associated with tectonic erosion. In

103 Costa Rica, offshore Osa Peninsula drilling through the regional unconformity during

104 Expeditions 334 and 344 recovered sands deposited in near shore conditions $(<100 \mathrm{~m}$ water

105 depth) at the base of the slope cover sequence, near the top of the margin wedge (Vannucchi, et

106 al., 2013; Expedition 344 Scientists, 2014). These sediments are currently at $600 \mathrm{~m}$ depth. If this

107 is a surf-zone related unconformity between the base of the slope cover and the margin wedge, it

108 is a structure that implies broad subsidence along all of Costa Rica and from beneath the shelf to

109 the lower slope. It is a distinctive manifestation of subsidence potentially due to basal erosion.

110 Similar unconformities are also seen beneath continental slopes of Nicaragua and Guatemala

111 (Ranero et al., 2007), and along the Peru, north Chile and Japan Trench margins, all of which are

112 thought to be erosive over a long time span (von Huene and Lallemand, 1990). 
114 structural elements within the margin, which reveal whether margins are largely the exposed

115 remains of the eroded margin core or accreted materials, largely sediment, transferred from the

116 subducting to the overriding plate (von Huene and Scholl, 1991). The Middle America Trench

117 convergent margin is made up of three principal elements (Ranero, et al., 2007): 1) a

118 comparatively high-seismic-velocity margin wedge (velocities of $4.5-5.5 \mathrm{~km} / \mathrm{s}$ were measured

119 within the margin wedge $\sim 80 \mathrm{~km}$ to the NW of our survey; Ye et al, 1998; Stavenhagen et al.

120 1998) that forms the bulk of the margin structure, 2) an overlying slope cover sequence, and 3) a

121 small frontal sediment prism with internal structures consistent with thrust faulting $(<10 \mathrm{~km}$

122 wide) that abuts the margin wedge (in this paper we interpret the "frontal prism" as an

123 accretionary wedge as discussed below; Figure 2). This structural configuration has been

124 interpreted as having been formed by tectonic erosion processes (Ranero et al., 2007). On the

125 basis of the relatively high seismic velocity and the discontinuous seismic reflections within the

126 margin wedge, the margin wedge has been interpreted to be a truncated (steeply tapered toward

127 the trench) piece of upper-plate crystalline basement rocks formed by Nicoya Ophiolite Complex

128 or crystalline and lithified rocks of the Osa Peninsula terranes (the Osa Igneous Complex and

129 Osa Melange; Buchs et al., 2009) (Hinz et al., 1996; Ranero and von Huene, 2000; Ranero, et al.,

130 2007). Ranero et al. (2007) infer that the core of the margin was exposed after landward retreat

131 due to tectonic erosion along the base and seaward edge of the margin, consistent with structures

132 associated with other erosional margins, e.g. Chile north of $\sim 32^{\circ} \mathrm{S}$ (von Huene and Ranero, 2003,

133 Ranero et al., 2006), the Aleutians (von Huene et al., 2012), Peru (von Huene and Lallemand,

134 1990; Clift et al., 2003), Ecuador (Sage et al., 2006). Along the Costa Rica margin, the margin

135 wedge is buried beneath $\sim 1 \mathrm{~km}$ of slope cover that extends from the shelf to the lower slope. Not 
136 surprisingly erosional margins typically have thin trench sequences $(<500 \mathrm{~m})$ that provide little

137 material for frontal accretion and are prone to be completely subducted. Drilling along the

138 Nicoya peninsula confirmed all but $\sim 7 \mathrm{~m}$ of the $\sim 500 \mathrm{~m}$ section is currently subducting (Kimura

139 et al., 1997). A small frontal prism was interpreted as consistent with a lack of accretion because

140 of ODP Leg 170 drilling near the Nicoya peninsula within the frontal prism that shows it is

141 composed largely re-worked slope sediment derived from the shelf and deposited along the

142 lower most trench slope (Kimura et al., 1997; Silver et al., 2000).

143 Thirdly, systems of normal faults that extend deep into the margin wedge are also a

144 distinctive structure associated with tectonic erosion (von Huene et al., 2004). Normal faults are

145 interpreted as a result of extension of the upper plate following removal of material along the

146 base of the upper plate that leads to collapse of the margin. Normal faults through the margin

147 wedge can be activated during interseismic periods when interseismic stress relaxation is

148 sufficiently extreme (Wang et al., 2010). Normal faulting cutting into the top of the wedge has

149 been mapped under the slope along the Nicaragua and Costa Rica margins (McIntosh et al.,

150 1993; Ranero and von Huene, 2000) and is regionally collocated with the unconformity

151 described above (Ranero et al., 2007).

153 3. Seismic data volume

154 We acquired the 3D seismic volume to the NW of the Osa Peninsula where the flank of

155 the Cocos Ridge and and Quepos guyot (produced by interaction of Galapagos Hot Spot and the

156 Cocos-Nazca spreading center) are currently subducting (Figure 1). We used two 52.4 L (3200

$157 \mathrm{in}^{3}$ ) airgun arrays fired alternately (each array was fired every $50 \mathrm{~m}$ ) as our source, and recorded

158 the arrivals on four six-km-long streamers towed with $150 \mathrm{~m}$ separation. We used a Kirchhoff 
$1593 \mathrm{D}$ prestack depth migration algorithm and multiple iterations of 3D velocity analysis to produce

160 high-quality, detailed images of the margin structure. Acquisition and processing details are

161 described in Bangs et al. (2015). These results produce the best images to date of the complex

162 structure of the overriding plate across the Costa Rican margin.

\section{4. The 3D Seismic Structure NW of the Osa peninsula}

\subsection{Regional Unconformity}

Figure 2 show an unconformity that separates the overlying slope cover from the

167 underlying margin wedge sequence. The unconformity is evident from both the high reflection

168 amplitude and terminations of underlying reflections at this horizon that are common throughout

169 the volume (e.g. Figure 2). We can trace a high-amplitude reflection and the overlying slope

170 cover sequence from beneath the shelf to the lower slope, although the strong seismic reflections

171 or stratal relationships that define the unconformity are not seen everywhere. Along the lower

172 slope the position of the unconformity is equivocal because of the greater conformity and low

173 impedance contrast between the slope cover and margin wedge sequences. The seaward

174 termination of the unconformity is also equivocal because of the greater deformation and

175 disruption of more seaward structures. The unconformity is also recognizable from higher

176 velocities and changes in seismic frequencies due to attenuation below the unconformity. By any

177 measure the unconformity is identifiable and extends broadly across the shelf and slope.

178 4.2 Structural Elements within the Margin

179 The slope cover sequence is well imaged, and stratal relationships within it are generally

180 interpretable throughout the volume. Despite moderate folding and fault displacement, slope

181 sediment sequences are easily recognizable as continuous strata that can be correlated laterally 
182 for 5 - $10 \mathrm{~km}$ (Figures 2-7) in both dip and strike directions. Drilling during Expeditions 334 and

183344 penetrated these sequences at Sites 1380, 1379 (10 km southeast of the 3D volume) and

1841413 (Figures $1 \mathrm{~b} \& 5$ ), and recovered layered sequences of clastic sediments ranging in lithology

185 from sands and sandstones to fine grained clays and claystones, with ages from recent to late

186 Pleistocene (Vannucchi, et al., 2013; Expedition 344 Scientists, 2014; Figure 5).

187 Along most of the 3D volume, the slope cover has been folded and faulted due to a series

188 of underlying discrete landward dipping thrust faults with 3-8 km spacing (fault spacing

189 broadens progressively landward; Figures 2, - 5; see Bangs et al., 2015 for more details). Layers

190 within the slope cover are not continuous across the entire sequence due to onlap and downlap of

191 sequences following the development of the folds within the underlying margin wedge indicating

192 the recent activity of these structures. However, through the middle of the volume (Figure 5),

193 folding and faulting is not as intense as other parts of the volume and provides an interpretable

194 window for the slope basin stratigraphy and insight into the recent deformation. Here, the

195 deepest slope sequence ( $\mathrm{a}$ in Figure 5) lies along the mid to lower slope and pinches out against

196 the underlying margin wedge on the landward side $\left(\mathrm{a}_{1}\right)$, and against margin wedge sequences on

197 the seaward side $\left(\mathrm{a}_{2}\right)$. On the basis of the geometry of the strata, the strata in the middle of this

198 slope basin have been displaced vertically above the crest of the fold, inverting the center of the

199 basin above the fold (Figure 6). The sequence (b) onlaps against the uplifted underlying

200 sequence (a) and margin wedge, while the shallower sequence (c) extends farther seaward to the

201 seaward edge of the basin (at c2), where it onlaps the folded slope cover and underlying margin

202 wedge. Assuming slope cover sequences (a-c) were deposited nearly horizontally, fault

203 displacements within the underlying margin wedge can be estimated approximately (Figure 6). 
204 All of these relationships reveal recent deformation that is consistent with the horizontal

205 shortening and uplift along thrust ramps within the underlying margin wedge and slope cover.

206 4.2.1 Margin Wedge

207 The largest improvements to images along this transect are within the margin wedge.

208 Despite persistent imaging difficulties due to reflector disruptions and discontinuities previously

209 noted by von Huene et al. (2000), there is now sufficient reflection coherency and continuity in

$2103 \mathrm{D}$ to reveal the detailed relationships between the layered fabric within the margin wedge,

211 faulting, and the overlying sediment strata, that was not previously interpretable in $2 \mathrm{D}$ sections.

212 Packets of parallel seismic reflections are semi-continuous, closely-spaced, and generally have a

213 landward dip (Figure 3). The layered sequences are folded into ridges with 3 - $8 \mathrm{~km}$ separation

214 (A- D in Figures 3, 4, 5, 7\& 8) that roughly parallel the margin and are bounded by thrust faults.

215 These folds generally increase in width from the lower slope (A) to the upper slope (D). The

216 folds and faults form a fault-propagation fold geometry with fold ramps parallel to layers near

217 the base of the fault, and with overturned layers within the fold that become perpendicular to

218 fault planes near the top of the fault (e.g. C in Figures $3 \&$ 7).

219 Collectively these reflective horizons within the margin wedge appear as a series of

220 imbricately stacked layered sequences (Figures 3-8). Faults bounding these folds generally have

221 less displacement toward the trench (e.g. Figure 5), and, where we have been able to measure

222 thicknesses of layers within thrust sequences reasonably well, there is a general thinning of

223 layers (e.g. from $\sim 1.8 \mathrm{~km}$ thick near (C) to $\sim 1.2 \mathrm{~km}$ near (A) in Figure 7; similarly in Figure 3).

224 We also note that the geometry of the fault propagation folds within the margin wedge parallels

225 the tilted and folded geometry of the overlying slope cover indicating continuous shortening and

226 thickening of the margin wedge during deposition of the slope cover. 
The fault-propagation folds are sufficiently coherent that their broad variations as folded

228 units are traceable along strike. The horizontal depth slice shown in Figure 4 intersects the

229 margin wedge from its seaward extent near the base of the lower slope (near A) across the shelf

230 break and shelf. The horizontal depth slice shows that the margin wedge beneath the slope is a

231 series of synclines and anticlines with a slight plunge to the SE (as indicated in the horizontal

232 slices by some terminations of the anticlines to the ESE, e.g. near D, and some termination of the

233 synclines to the WNW, between B and C), with most of the folds extending across the entire 11

$234 \mathrm{~km}$ of the 3D volume, and with some merging along strike into a broader fold (c.f. A and B along

235 the crossline direction in Figure 4). The dip is slightly oblique to the convergence direction,

236 which is parallel to the inline profiles (Figure 1).

237 4.2.2 Accretionary wedge (frontal prism)

238 A small $(<10 \mathrm{~km})$ frontal accretionary wedge along the toe of the slope forms from

239 imbricate stacks of sediments scraped off of the incoming trench sequence with some slope cover

240 material deposited on top of the accretionary wedge (Figures $2 \& 9$ ). This wedge was interpreted

241 as a "frontal prism" because it was believed to be composed entirely of sediments shed from the

242 shelf and slope and incorporated into the frontal wedge rather than sediments scraped off the

243 subducting plate. In these new profiles, we see approximately half of the $400-450 \mathrm{~m}$ of

244 sediment in the trench is accreted into the wedge and half lies beneath the decollement. The bulk

245 of the accretionary wedge is accreted sediment and not slope cover sequences, which is

246 consistent with observations of repeated trench sediment sequences recovered from drilling at

247 Site $1412 \sim 10 \mathrm{~km}$ to the SE of the 3D volume (Expedition 344 Scientists, 2013). 
Sets of intersecting normal faults are pervasive throughout the slope cover sequences

251 across the shelf and down the mid to lower slope (e.g. Figure 5; see Bangs et al. (2015) and

252 Kluesner et al. (2013) for more examples). Normal faults typically have $\sim 200 \mathrm{~m}$ spacing;

253 however, they have very minimal offset $<25 \mathrm{~m}$ and can only be seen well in close up view

254 (Figure 5a \& 5b). A primary set has orientations generally NNE-SSW across the shelf (F-1 and

255 F-2 in Figure 5b), and mid-slope, and possibly onto areas of the lower slope; however, they

256 become increasingly more difficult to correctly identify in the disrupted lower slope strata. Other

257 sets of normal faults and ENE-WSW (F-3 and F-4 in Figure 5b) have less offset and are harder to

258 identify. The key observation within the 3D volume and not previously seen in $2 \mathrm{D}$ images is the

259 shallow extent of the normal faults (Figure 5a). Nearly all of the normal faults penetrate no

260 deeper than the slope cover sequences and few extend deeper than the top of the margin wedge

261 (e.g. Figure 5a). The frontal $\sim 20-30 \mathrm{~km}$ of the margin wedge at least is dominated by thrust ore

262 reverse faults only (Bangs et al., 2015). Normal faults across the shelf and upper slope are

263 associated with regional stresses (Malinverno et al., 2015), but many of the normal faults along

264 the mid to upper slope are shallow penetrating faults possibly caused by shallow extension above

265 folds within the underlying margin wedge.

$267 \quad \mathbf{5 . 0}$ Tectonic history of the margin wedge

268 While structures associated with tectonic erosion, such as the regional unconformity,

269 minimal trench sediment, and observations of normal faults, are certainly evident within the 3D

270 volume, much of what appears in the 3D volume is actually inconsistent with structures

271 associated with tectonic erosion. There is still considerable complexity beyond our resolution, 
272 but two of the three key structures associated with tectonic erosion do not fit a model of

273 continuous Neogene tectonic erosion.

274 First and foremost, the margin wedge beneath the slope and at least some portion of the

275 outer shelf is made up of layered sequences that have been shortened by thrust faulting and

276 folding and have been imbricately stacked (Figures 2-8). The long laterally continuous layering

277 suggests these are clastic sediments; this is also consistent with sediment recovered during

278 Expedition 344 at Site 1380. Drilling penetrated the entire Pleistocene slope sequence and an

279 additional $~ 300 \mathrm{~m}$ into the Pliocene margin wedge, where coring recovered silts and clays, with

280 occasional thin sand layers (Expedition 344 Scientists, 2013). We presume that these sediments

281 were initially deposited on a stable basement in order for these clastic sediment layers to develop

282 their broad (10's of km) lateral continuity shown in Figures 3-5, $7 \& 8$ and were then later

283 subjected to compressional deformation and shortening. Based on the larger fault offsets and

284 tighter folds of the margin wedge relative to the overlying slope cover (Figure 7), an extensive

285 amount of shortening began prior to the development of the unconformity and slope cover

286 sedimentation. Furthermore the coincident fold geometry of the slope cover suggests margin

287 wedge shortening continued during slope sequence deposition and remains active currently,

288 although activity in the last $\sim 1 \mathrm{~m} . \mathrm{y}$. has declined and recent deformation is minimal. We presume

289 the predominance of thrusting is in response to consistently strong basal tractions from the

290 subducting plate and generally inconsistent with extension and collapse of the margin from basal

291 erosion (e.g. von Huene et al. 2004). The general decrease in thrust fault displacement from

292 landward to seaward is consistent with its growth as a coulomb wedge by frontal accretion as it

293 maintained its critical wedge taper (Davis et al., 1983). The consequence of the compressional

294 deformation is substantial shortening of up to at least $30 \%$ (e.g. Figure 7) into a continuous 
series of stacked sequences with no apparent breaks or discontinuities that might be associated

296 with temporal changes from compressional to an extensional stress regime.

297 Secondly, there is an extensive normal fault system within the 3D volume; however,

298 these faults are limited to the slope cover, exhibit small offsets, and rarely extend into the margin

299 wedge. They are not through-going normal faults that extend through the overriding plate and do

300 not appear to be associated with collapse of the margin. In fact, the margin wedge faults are

301 almost all thrust faults consistent with continuous compression and there are no indications of

302 periods of extension. Shallow normal faults are not unusual with accretionary systems as

303 observed with the Nankai accretionary margin where uplift within the inner wedge leads to

304 shallow extension (Moore et al., 2013); however, extension is broadly distributed across the

305 Costa Rica margin and not localized along a splay fault system as it is in Nankai.

There is also evidence that at least the frontal $30 \mathrm{~km}$ of the margin-wedge structure

307 within the 3D volume is more consistent with accretion during its formation than erosion. The

308 structure of the slope cover is even clearer than the structures of the underlying margin wedge

309 and it reveals recent tectonic history of the margin wedge. Since the development of the

310 unconformity, the slope cover sequence records a history of uplift of the frontal sequence. The

311 3D images show a layered sequence currently being thrust under the downslope edge of the

312 margin wedge. We interpret this thrust ramp (lower thrust in Figures $5 \& 6$ ) as the cause of uplift

313 of the seaward most corner of the margin wedge. We note that the amount of uplift is

314 approximately equal to the thickness of the section beneath the lower interpreted thrust fault and

315 follows the approximate geometry of the thrust fault ramp. This coincident geometry is

316 compelling evidence that deformation arises from uplift during thrusting along this ramp, which

317 created the slope basin (between b1 and c2). Uplift by thrusting along this ramp began early in 
318 the history of slope cover deposition, it continued episodically throughout the basin history,

319 creating Ridge A/B in Figure 5, and it appears to continue today. These observations are

320 consistent with an accretionary context.

321

322 6.0 Massive Erosion or episodic Accretion?

323 The critical new observation is that the margin wedge beneath the slope, imaged in the

324 Costa Rica 3D seismic data, has long, continuous layers of clastic sediment and is not composed

325 of crystalline basement. This observation must be accommodated in an interpretation of the

326 tectonic history of this margin. Two likely end-member scenarios fit most of the observations.

327 The margin wedge could be composed of forearc basin sediments that were deposited on

328 a stable forearc basement and have subsequently been thrust and thickened into the margin

329 wedge. If this is the case, the forearc basement that formed the stable depositional platform

330 would prevent or severely impede thrusting and thickening of any overlying forearc basin

331 sediment unless the basement was thinned or removed, presumably by massive tectonic erosion

332 (Vannucchi et al., 2013). If this happens by piecemeal erosion of a forearc basement in a fashion

333 consistent with erosional models (von Huene et al., 2004), then it must have happened without

334 producing many of the expected structures associated with tectonic erosion described above such

335 as through-going normal faults. There is also no evidence for an older forearc basement, or other

336 indications of tectonic disruption of the margin wedge during an episode of massive tectonic

337 erosion of an underlying forearc basement. An alternative to piecemeal erosion of a forearc

338 basement, tectonic erosion could have happened by rapid wholescale removal of a forearc

339 basement, but again there is no structural evidence within the margin wedge for what most likely

340 would be an even more massive tectonic disruption. 
As an alternative to erosion, the margin wedge could be sediment that was recently and

342 rapidly deposited in the trench and subsequently accreted. There is currently little sediment $(\sim$

$343400 \mathrm{~m}$ ) on the incoming plate or deposited in the trench along the 3D survey area (Figures $1 \& 9$;

344 Bangs et al., 2015). This may be in large part due to the rapid subduction and the presence of the

345 Cocos Ridge, which has created a very shallow trench. The current geometry is more favorable

346 to sediment deposition on the shelf and slope rather than in the trench. While there currently is

347 some frontal accretion, accretion is minimal because of the lack of trench sediment. However,

348 past plate geometry was much more conducive to rapid sediment deposition and thick sediment

349 accumulation in the trench and lower slope. As described by MacMillan et al., (2004), the

350 southward migration of the Cocos-Nazca-Caribbean triple junction $\sim 4.5 \mathrm{Ma}$ (Figure 1a) resulted

351 in $\sim 2 \mathrm{~km}$ of subsidence of the trench and overriding plate. This occurred as the Panama-Coiba

352 fracture zone system migrated south and the thick crust of the Nazca plate, possibly generated in

353 the Miocene at the Samba Ridge (Morell, 2015) and associated with the fracture zones and the

354 Coiba Ridge, was replaced with thinner crust. Passing of the triple junction also initiated rapid

355 orthogonal convergence. A large sediment supply to the trench following rapid deposition of the

356 trench basin created by the passing triple junction may have created an opportunity for frontal

357 accretion of the trench sediments. Thick sediment sequences are currently deposited on the

358 subducting crust in the Manila trench offshore Taiwan and accreted in thrust sequences with a

359 geometry similar to the margin wedge thrust sequences in Costa Rica (Lester et al., 2013). The

360 accretionary wedge along the lower slope of Taiwan margin also has a seaward decreasing fold

361 spacing, which we see in Costa Rica (e.g. Figure 7b), and a seaward thinning of the incoming

362 sediment section due to the geometry of the top of subducting ocean crust, which we speculate

363 existed during accretion in southern Costa Rica prior to the approach of the Cocos Ridge. 
364 Despite the lack of significant incoming sediment now, the fact that we see long continuous

365 sequences within the margin wedge is consistent with an accretionary context. Furthermore, the

366 observation that margin wedge stratigraphic sequences are progressively thinner toward the

367 trench is consistent with thinning of more recent incoming trench sediment sequences. We

368 speculate that a thick incoming section existed since the passage of the triple junction, which led

369 to a brief ( $\sim .5$ to $\sim 2.0 \mathrm{Ma})$ episode of accretion along this margin. After the passage of the

370 triple junction and the Coiba ridge, the trench basin became elevated with the advance of the

371 Cocos Ridge, trench sedimentation declined, and trench sequences progressively thinned causing

372 accretion to progressively cease almost completely to what is actively accreting at the toe now.

373 This may have occurred simultaneously with trench retreat from Cocos Ridge collision that

374 Fisher et al (2004) attribute to inner forearc shortening along the Fila Costeña thrust belt.

375 What remains unclear for an accretionary scenario is how the unconformity developed

376 and how the uplift and subsidence associated with the unconformity fit into an accretionary

377 context. Dynamic changes in plate boundary geometry (Regalla et al., 2013) are a possible

378 mechanism for generating a broad unconformity. Uplift and subsidence could also be a result of

379 aseismic ridge or seamount subduction; however, we have no direct evidence for subduction of

380 any specific feature. Local aseismic ridge subduction is certainly possible or maybe even

381 expected within the 3D volume depending on the downdip continuity of the incoming

382 bathymetric ridges on the Cocos plate (e.g. the Quepos ridge in Figure 1). A ridge subducted 2

383 Ma would have passed completely through our survey area by $\sim 1.5 \mathrm{Ma}$ and be difficult to detect

384 now, but it would only have local uplift or erosional effects and any resulting unconformity

385 would be localized. It could explain the unconformity within the 3D volume, but then it would

386 not be part of a broader unconformity related to tectonic erosion. With limited age control and 
poor along strike correlation it is unclear if there is a genetic link between the unconformities

388 across broad regions of the Middle America margin or if localized unconformities due to

389 aseismic ridge subduction are more likely than a broader regional unconformity. In any case, the

390 structure within the southern Costa Rica margin seen in 3D images is consistent with a period of

391 margin accretion. This relatively brief phase of accretion has constructed a proportionally large

392 volume along the margin in a relatively brief period of the margin's history. This observation

393 implies that the recent phase of accretion was not sustained throughout the Neogene, and the

394 history of the margin likely includes other periods of accretion, non-accretion or erosion.

395 It remains to be seen whether there are more areas of accretion along the Middle America 396 margin, or if this is a localized characteristic of southern Costa Rica. Erosion along Costa Rica

397 broadly may be localized and limited to effects of aseismic ridge or seamount subduction rather

398 than broadly extensive. Answering this question will require high-quality images like the 3D

399 images shown here, to provide a more complete picture of the Middle America convergent 400 margin structure.

\section{$401 \quad 7.0$ Acknowledgments}

402 We thank Don Fisher for helpful comments on an earlier version of this manuscript. We 403 appreciate EPSL reviewers Kristin Morell and Lisa McNeill for providing constructive and 404 thorough reviews that helped the manuscript greatly. We thank Paradigm Geophysical for 405 Geodepth and Echos software packages used for data processing and interpretation. We thank 406 Repsol in the Woodlands, TX for assistance with data processing and generous contributions of 407 computer resources for 3D prestack depth migration. This work was supported by National 408 Science Foundation grant numbers 1435386 and 1457221 . This is UTIG contribution \# 409 
412 Bangs, N. L., K. D. McIntosh, E. A. Silver, J. W. Kluesner, and C. R. Ranero (2015), Fluid accumulation 413 along the Costa Rica subduction thrust and development of the seismogenic zone, J. Geophys. Res. 414 Solid Earth, 120, 67-86, doi:10.1002/2014JB011265.

415 Buchs, D.M., P.O. Baumgartner, C. Baumgartner-Mora, A.N. Bandini, S.-J. Jackett, M.-O.

416 Diserens, J. Stucki, Late Cretaceous to Miocene seamount accretion and mélange formation 417 in the Osa and Burica Peninsulas (Southern Costa Rica): episodic growth of a convergent 418 margin, K. James, M.A. Lorente, J. Pindell (Eds.), The Origin and Evolution of the 419 Caribbean Plate (2009), pp. 411-456

420 Christeson, G. L., K. D. McIntosh, T. H. Shipley, E. R. Flueh, H. Goedde, (1999), Structure of the Costa 421 Rica convergent margin, offshore Nicoya Peninsula, Jour. Geophys. Res., 104, 25,443-25,468.

422 Clift, P.D., and Vannucchi, P., (2004), Controls on tectonic accretion versus erosion in subduction zones: 423 Implications for the origin and recycling of the continental crust: Review of Geophysics, v. 42, $424 \quad$ RG2001, doi:10.1029/2003RG000127.

425 Clift, P.D., Pecher, I., Kukowski, N., and Hampel, A., (2003), Tectonic erosion of the Peruvian forearc, 426 Lima Basin, by subduction and Nazca Ridge collision: Tectonics, v. 22, no. 3, doi:

$427 \quad 10.1029 / 2002$ TC001386.

428 Davis D, J. Suppe, F. A. Dahlen. (1983), Mechanics of fold-and-thrust belts and accretionary wedges, $J$. 429 Geophys. Res., 88: 1153-72.

430 Expedition 344 Scientists, (2013), Costa Rica Seismogenesis Project, Program A Stage 2 (CRISP-A2):

431 sampling and quantifying lithologic inputs and fluid inputs and outputs of the seismogenic zone.

432 IODP Prel. Rept., 344. doi:10.2204/iodp.pr.344.2013. 
433 Fisher, D. M., T. W. Gardner, P. Sak, J. D. Sanchez, K. Murphy, and P. Vannucchi (2004), Active

434 thrusting in the inner forearc of an erosive convergent margin, Pacific coast, Costa Rica, Tectonics,

435 23, TC2007, doi:10.1029/2002TC001464.

436 Hinz, K., R. von Huene and C.R. Ranero, PACOMAR Working Group, (1996), Tectonic structure of the

437 convergent Pacific margin offshore Costa Rica from multichannel seismic reflection data, Tectonics, $438 \quad 15,54-66$.

439 Kimura, G., et al., (1997): Ocean Drilling Program: Proceedings of the Ocean Drilling Program Initial $440 \quad$ Reports 170, College Station, Texas, 1997.

441 Kluesner, J. W., E. A. Silver, N. L. Bangs, K. D. McIntosh, J. Gibson, D. Orange, C. R. Ranero, R. von 442 Huene, (2013), High Density of Structurally-Controlled, Shallow to Deep Water Fluid Seep

443 Indicators Imaged Offshore Costa Rica, Geochem, Geophys., Geosyst., 14, 2013, DOI:

$444 \quad 10.1002 /$ ggge.20058.

445 Lester, R., K. McIntosh, H. J. A. van Avendonk, L. Lavier, C-S. Lui, T. K. Wang, (2013), Crustal

446 accretion in the Manil trench accretionary wedge at the transition from subduction to mountain-

447 building in Taiwan, Earth Planet. Sci. Lett., 375, 430-440.

448 MacMillan, I., P. B. Gans, and G. Alvarado, (2004), Middle Miocene to present plate tectonic history of

449 the southern Central American Volcanic Arc, Tectonophysics, 392(1-4)325-348.

$450 \quad$ doi:10.1016/j.tecto.2004.04.014.

451 Malinverno, A., S. Saito, P. Vannucchi, Horizontal principal stress orientation in the Costa Rica

452 Seismogenesis Project (CRISP) transect from borehole breakouts, Geochem., Geophys., Geosyst., 453 in press.

454 McIntosh, K., E. Silver, and T. Shipley, (1993), Evidence and mechanisms for forearc extension at the 455 accretionary Costa Rica convergent margin, Tectonics,12(6):1380-1392. doi:10.1029/93TC01792. 
Moore, G. F., B. B. Boston, A. F. Sacks, D. M. Saffer, (2013), Analysis of normal fault populations in the Kumano Forearc Basin, Nankai Trough, Japan: 1. Multiple orientations and generations of faults from 3-D coherency mapping, Geochem. Geophys. Geosyst., 114, 1989-2002, doi:10.1002/ggge.20119.

Morell, K., 2015 Late Miocene to recent plate tectonic history of the southern Central America convergent margin, Geochem. Geophys. Geosyst., 16, 3362-3382, doi:10.1002/2015GC005971.

Ranero, C. R., R. von Huene, W. Weinrebe, U. Barckhausen, (2007), Convergent margin tectonics: A marine perspective, In: Bundschuh, J. ; Alvarado, G. E. (Ed.) : Central America - Geology, Resources and Hazards, Oxford : Taylor and Francis, pp 26 pp. - ISBN 0415416477

Ranero, C. R.; von Huene, R.; Weinrebe, W. and Reichert, C. Tectonic Processes along the Chile Convergent Margin, (2006). In: Oncken, O., Chong, G., Franz, G., Giese, P., Götze, H.-J., Ramos, V., Strecker, M., Wigger, P. (eds): The Andes - Active Subduction Orogeny. Frontiers in Earth Sciences, vol. 1, XXII, pp. 91-121, Springer, Berlin, Heidelberg.

Ranero, C.R., and R. von Huene, (2000), Subduction erosion along the Middle America convergent margin. Nature, 404(6779):748-752. doi:10.1038/35008046.

Ranero, C. R. , R. von Huene, E. Flueh, M. Duarte, D. Baca, K. McIntosh, (2000), A cross section of the Pacific Margin of Nicaragua, Tectonics, 19, 2, 335-357.

Regalla, C. D. M. Fisher, E. Kirby, K. P. Furlong, (2013), Relationship between outer forearc subsidence and plate boundary kinematics along the Northeast Japan convergent margin, Geochemistry, Geophysics, Geosystems, 14, $5227-5243$.

Saffer, D. M. and H. J. Tobin, (2011), Hydrogeology and mechanics of subduction zone forearcs: Fluid flow and pore pressure, Annu. Rev. Earth Planet Sci., 39: 157-186.

Sage, F., J.-Y. Collot C. R. Ranero, (2006), Interplate patchiness and subduction-erosion mechanisms: Evidence from depth-migrated seismic images at the central Ecuador convergent margin, Geology, v. 34, p. 997-1000, doi: 10.1130/G22790A.1. 
Shipley, T.H.,K. D. McIntosh, E. A. Silver, and P. L. Stoffa, (1992), Three-dimensional seismic imaging of the Costa Rica accretionary prism: structural diversity in a small volume of the lower slope, $J$. Geophys. Res., 97(B4):4439-4459. doi:10.1029/91JB02999.

Silver, E., M. Kastner, A. Fisher, J. Morris, K. McIntosh, and D. Saffer, (2000), Fluid flow paths in the Middle America Trench and Costa Rica margin, Geology, 28(8):679-682. doi:10.1130/00917613(2000)28<679:FFPITM>2.0.CO;2.

Stavenhagen, A.U., E. R. Flueh, C. Ranero, K. D. McIntosh, T. H Shipley, G. Leandro, A. Schulze, and J. J. Dañobeitia, (1998) Seismic wide-angle investigations in Costa Rica - Crustal velocity model from the pacific to the Caribbean coast, Zentralbl, Geol. Paläeont. Teil I, 3-6, 393-408.

Vannucchi, P., Ranero, C. R., Galeotti, S., Straub, S. M., Scholl, D.W., McDougall-Ried., (2003), Fast rates of subduction erosion along the Costa Rica Pacific margin: implications for non-steady rates of crustal recycling at subduction zones. Journal of Geophysical Research 108, 2511, $10.1029 / 2002 J B 002207$.

Vannucchi, P., Galeotti, S., Clift, P., Ranero, C. R.,. von Huene, R., (2004), Long term subduction along the Middle America Trench offshore Guatemala. Geology 32, 617-620.

Vannucchi, P., P. B. Sak, J. P. Morgan, K. Ohkushi, K. Ujiie, and the IODP Expedition 334 Shipboard Scientists, (2013), Rapid pulses of uplift, subsidence, and subduction erosion offshore Central America: Implications for building the rock record of convergent margins, Geology, 41, 995-998. von Huene, R. J. J. Miller, W. Weinrebe, (2012), Subducting plate geology in three great earthquake ruptures of the western Alaska margin, Kodiak to Unimak, Geosphere, 8, 628-644.

von Huene, R. and S. Lallemand, (1990), Tectonic erosion at the front of the Japan and Peru convergent margins, Geol. Soc. Am. Bull., 102, 704-720.

von Huene, R., D. W. Scholl, (1991), Observations at convergent margins concerning sediment subduction, erosion, and the growth of continental crust, Reviews of Geophysics, v. 29, p. 279-316, doi: 10.1029/91RG00969. 
von Huene, R., C. R. Ranero, and P. Vannucchi, (2004), Generic model of subduction erosion, Geology, v. 32, p. 913-916, doi: 10.1130/G20563.1.

von Huene, R., and C. R. Ranero, (2003), Subduction erosion and basal friction along the sedimentstarved convergent margin off Antofagasta, Chile, J. Geophys. Res., 108 (B2), 2079, doi:10.1029/2001JB001569.

von Huene, R., C. R. Ranero, W. Weinrebe, and K. Hinz, (2000), Quaternary convergent margin tectonics of Costa Rica, segmentation of the Cocos Plate, and Central American volcanism, Tectonics,

Wang K., Hu Y., von Huene R., Kukowski N., (2010), Interplate earthquakes as a driver of shallow 19(2):314-334. doi:10.1029/1999tc001143. subduction erosion: Geology, v. 38, p. 431-434, doi: 10.1130/G30597.1.

Yáñez, G. A.; Ranero, C. R.; von Huene, R. And J. Díaz, (2001), A tectonic interpretation of magnetic anomalies across a segment of the convergent margin of the Southern Central Andes $\left(32^{\circ}-34^{\circ} \mathrm{S}\right)$. Journal of Geophysical. Research 106, 6325-6345.

Ye, S., J. Bialas, E.R. Flueh, A. Stavenhagen, R, von Huene, G. Leandro, and K. Hinz, 1996, Crustal structure of the Middle American Trench off Costa Rica from wide-angle seismic data, Tectonics, 15,

\section{FIGURE CAPTIONS}

Figure 1a. Regional map of the Central America margin showing the Leg 170 and Leg 205 drill

527 sites near the Nicoya Peninsula, the 3D survey area near the Osa Peninsula, and the IODP

528 Expedition 334 and 344 drilling transect. Also shown is the intersection of the Coiba fracture

529 zone and the trench through time (black line) with approximated ages (white circles) (from 
MacMillan et al. 2004). Note that the trench Coiba FZ. formed the Cocos-Nazca-Caribbean plate

531 triple junction until the formation of the Panama FZ 2 Ma. 1b.) Bathymetric map showing 3D

532 seismic survey (red rectangle) location offshore of Osa Peninsula, Costa Rica. Stars locate two

533 recent thrust earthquakes. Orange and green circles mark the Expedition 334 and 344 drill sites

534 respectively.

536 Figure 2 Perspective overview of the 3D volume to show the major margin structures. The main

537 elements of the upper plate are: 1) an accretionary wedge (equivalent to the frontal prism in

538 Ranero et al., 2000); 2) the margin wedge, which is the wedge shaped body extending from

539 beneath the shelf, across the shelf break to the base of the slope (white arrow) and merges

540 gradually into the accretionary wedge; 3) the slope cover sediments that have been shed from the

541 margin and deposited on top of the margin wedge.

543 Figure 3. 3D perspective view of the margin wedge across the mid-slope region. Black line 544 marks the unconformity separating the slope cover from the underlying margin wedge. Ridges

545 A-C (also shown in Figures 4,5,7 \& 8) are fault-propagation folds that form thrust ridges. Blue

546 dashed lines marks the folded and faulted layered fabric within the margin. Red lines show thrust

547 faults separating thrust ridges. Note the continuity of layering along strike, the structural

548 continuity between thrust ridges of the margin wedge and overlying slope cover, and the

549 progressive decrease in shortening between the margin wedge and younger and younger slope

550 cover. Also note the absence of normal faults or extensional structures through the margin

551 wedge. 
553 Figure 4. Chair cut of the 3D volume with a depth slice through the margin wedge from the

554 lower slope to beneath the shelf showing the along strike continuity of folded stratigraphic

555 layers. Stratigraphic layers (blue dashed lines) are folded within thrust ridges (A-C; shown in

556 profile Figures $3,5,7 \& 8$ ) that extend along strike across the $11 \mathrm{~km}$ width of the 3D volume and

557 plunge slightly to the NE (into the page). An unconformity (black line) separates the slope cover

558 from the underlying margin wedge. The main faults (red lines) are thrust faults and separate

559 thrust ridges (e.g. near C) or intersect ridges (near D)

561 Figure 5. a) Enlargement of slope cover sequences along line 2320 showing small offset normal

562 faults across the upper slope. Note the small offsets $(<25 \mathrm{~m})$ and the shallow depth extent of

563 these faults. The normal faults terminate above the top of the margin wedge. These normal faults

564 are typical of all of the normal faults observed within the 3D volume. b) Three-dimensional

565 perspective view of the normal slope cover normal faults showing their orientation. Faults are

566 recognizable in both profile and horizontal depth slices. These faults form two sets of conjugate

567 normal fault pairs oriented ENE-WSW (F-1\&2) and ENE-WSW (F-3\&4). Note the shallow

568 unconformity within the slope cover is not the regional unconformity at the top of the margin

569 wedge. The normal faults terminate below the shallow unconformity and above the top of the

570 margin wedge.

571 c) Inline 2320 (dip line) through the middle of the 3D volume showing the relationship between

572 thrusting within the margin wedge and slope sediment sequence stratigraphy (see text and Figure

5736 for interpretation). Box shows locations of enlargements shown in a) and b).

574 d) Interpreted section shown in c). Slope cover sequences (a-c) are separated by light blue lines.

575 An unconformity separating slope cover from the margin wedge produces a large amplitude 
576 seismic reflection (black line). Thrust sequences are bounded by faults (red lines). Dashed blue

577 lines show continuous, deformed stratigraphic horizons. Sediment ages are approximated by

578 projection from roughly equivalent sequences in nearby Expedition 344 drill sites.

580 Figure 6. Schematic cartoon of kinematic movement within the margin wedge along Inline 2320

581 (Figure 5) to show a possible deformation history within the margin wedge. Movement is based

582 on the constraint that slope cover stratigraphic sequences (a-c) were deposited approximately

583 horizontally and subsequently deformed by shortening within the margin wedge (brown shading)

584 by slip along discrete thrusts (red lines). Dashed blue lines are stratigraphic horizons within the

585 margin wedge. Light blue lines are stratigraphic horizons within the slope cover (yellow

586 shading). Red arrows show slip displacement necessary to produce a nearly horizontal seafloor

587 deposition surface. Note that slip is distributed across the margin wedge, although it has been

588 limited to the lower slope in recent years.

590 Figure 7. Two profiles from the mid-slope region showing the slope cover, margin wedge, and 591 subducting crust through the middle of the 3D volume and through the SE edge of the volume.

592 Blue dashed lines follow stratigraphic horizons within the slope cover and underlying margin

593 wedge. Red lines are two faults that show the extent of slip is substantially larger within the

594 older, deeper, and more landward portions of the margin wedge. The margin wedge stratigraphic

595 layers thin toward the trench. Folds within the margin wedge shorten toward the trench, which is

596 typical throughout the 3D volume. Percentages are the amount of shortening along the respective

597 horizons assuming they formed straight lines initially. Arrows show layering within the margin

598 wedge that is interpreted as layered clastic sediment. 
$600 \quad$ Figure 8.

601 Three-dimensional perspective view of thrust and fold sequences within the margin wedge.

602 Letters show folds corresponding to those shown in Figures 3,4,5, \& 7. Folds B and C are folded

603 in both dip and strike directions as indicated by the dipping strata within the thrust sequence

604 (between blue lines).

605

606 Figure 9.

607 Seismic Inline 2098 (with interpreted section) from the trench, across the deformation front, the

608 accretionary wedge and the seaward most part of the margin wedge. Note the decollement

609 initiates midway down the $\sim 400 \mathrm{~m}$ thick incoming trench section. Consequently, $\sim 200 \mathrm{~m}$

610 sections are accreted at the toe to form the frontal accretionary wedge. Red lines follow thrust

611 faults and the decollement. Blue lines follow stratigraphic horizons. Green line follows the top of

612 the ocean crust.

613 


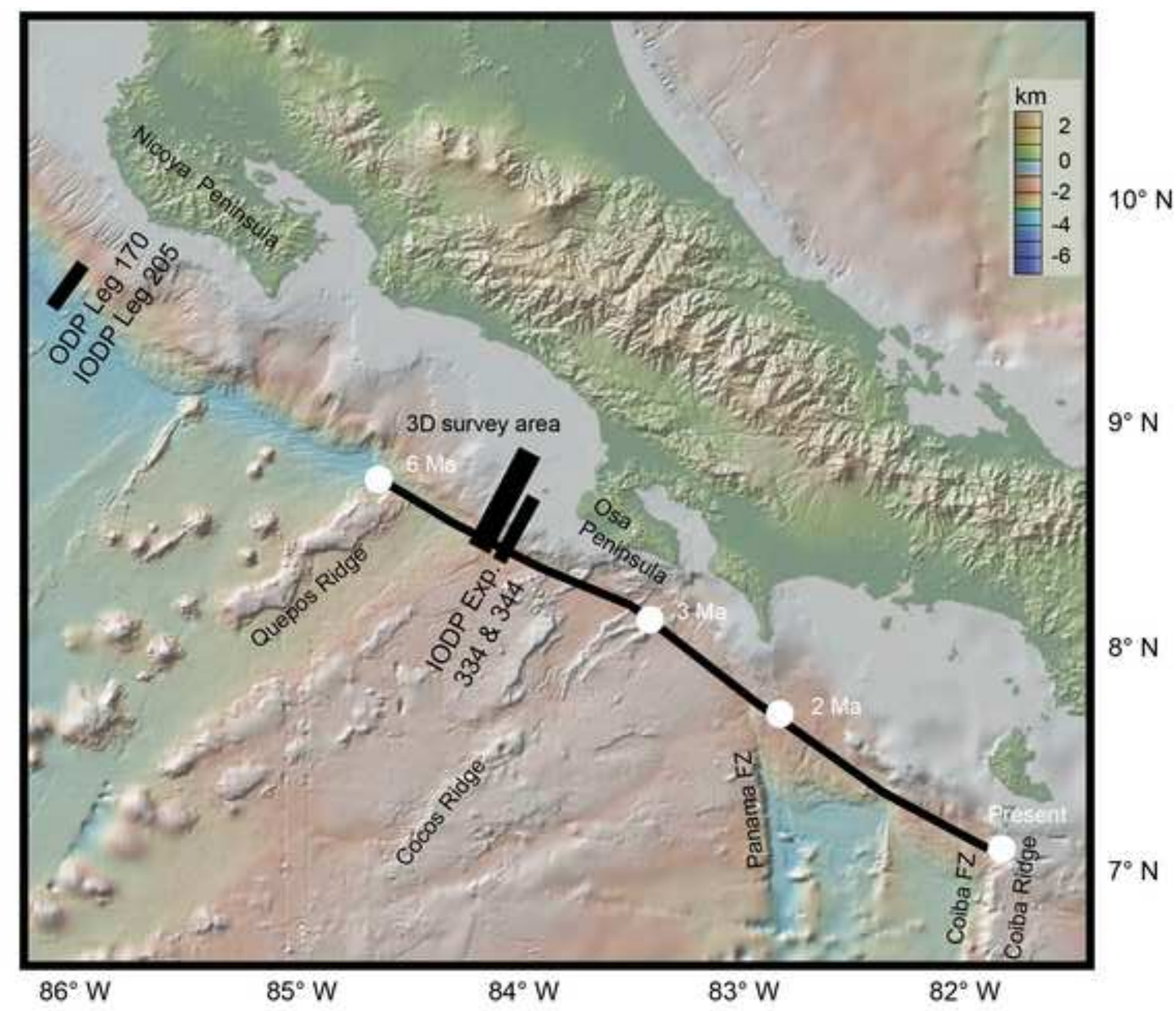

Figure 1a 


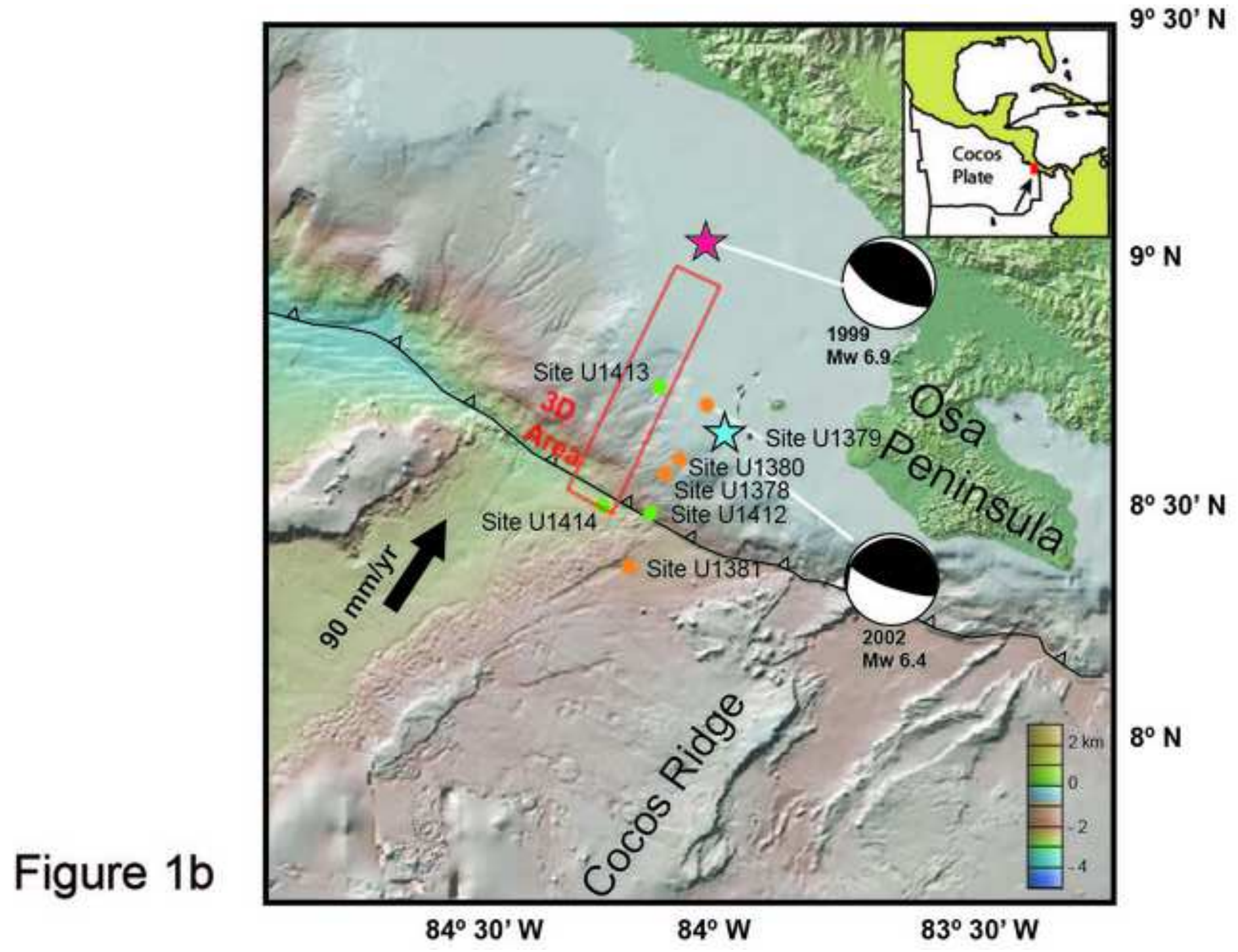




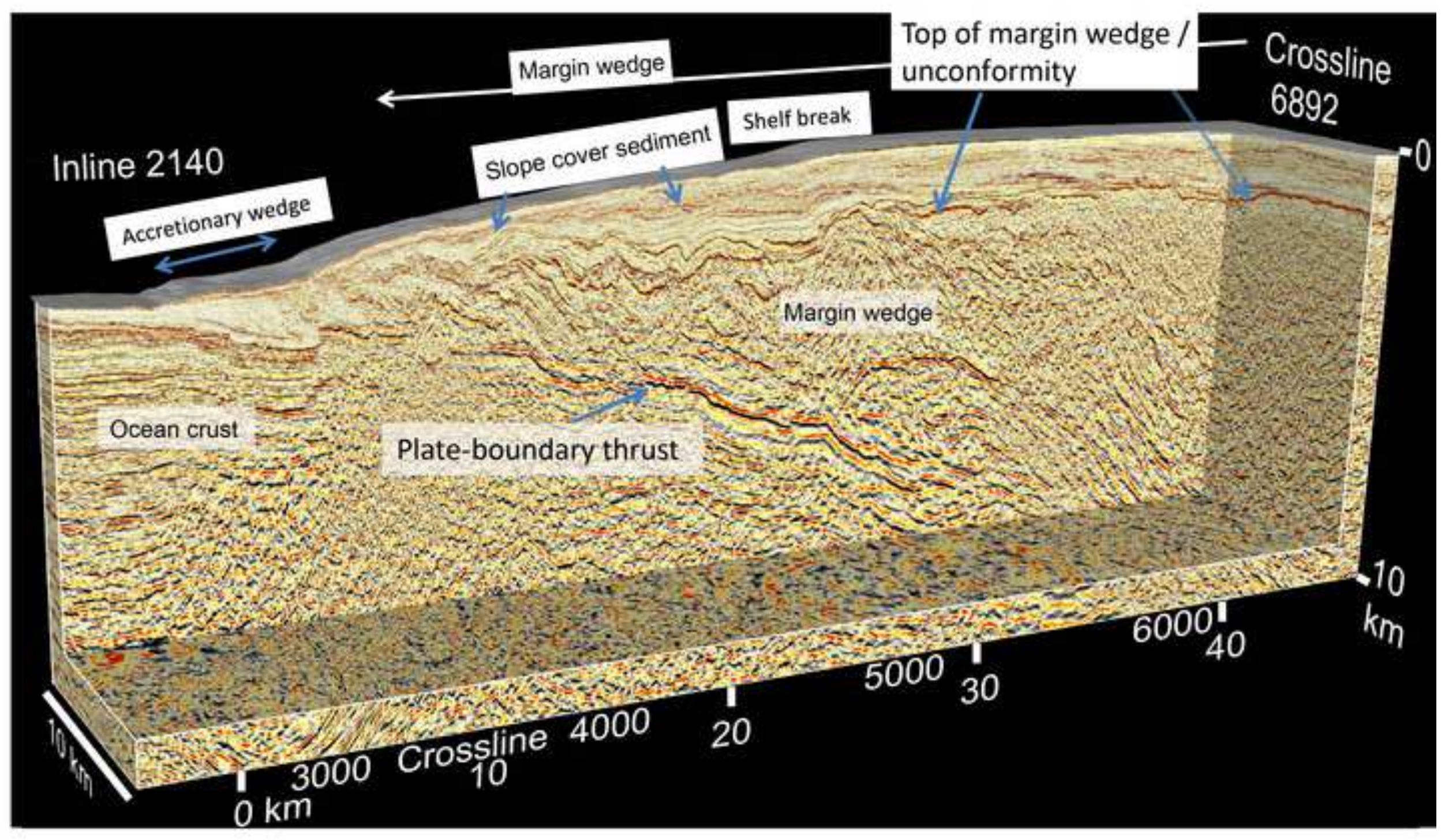

Figure 2 

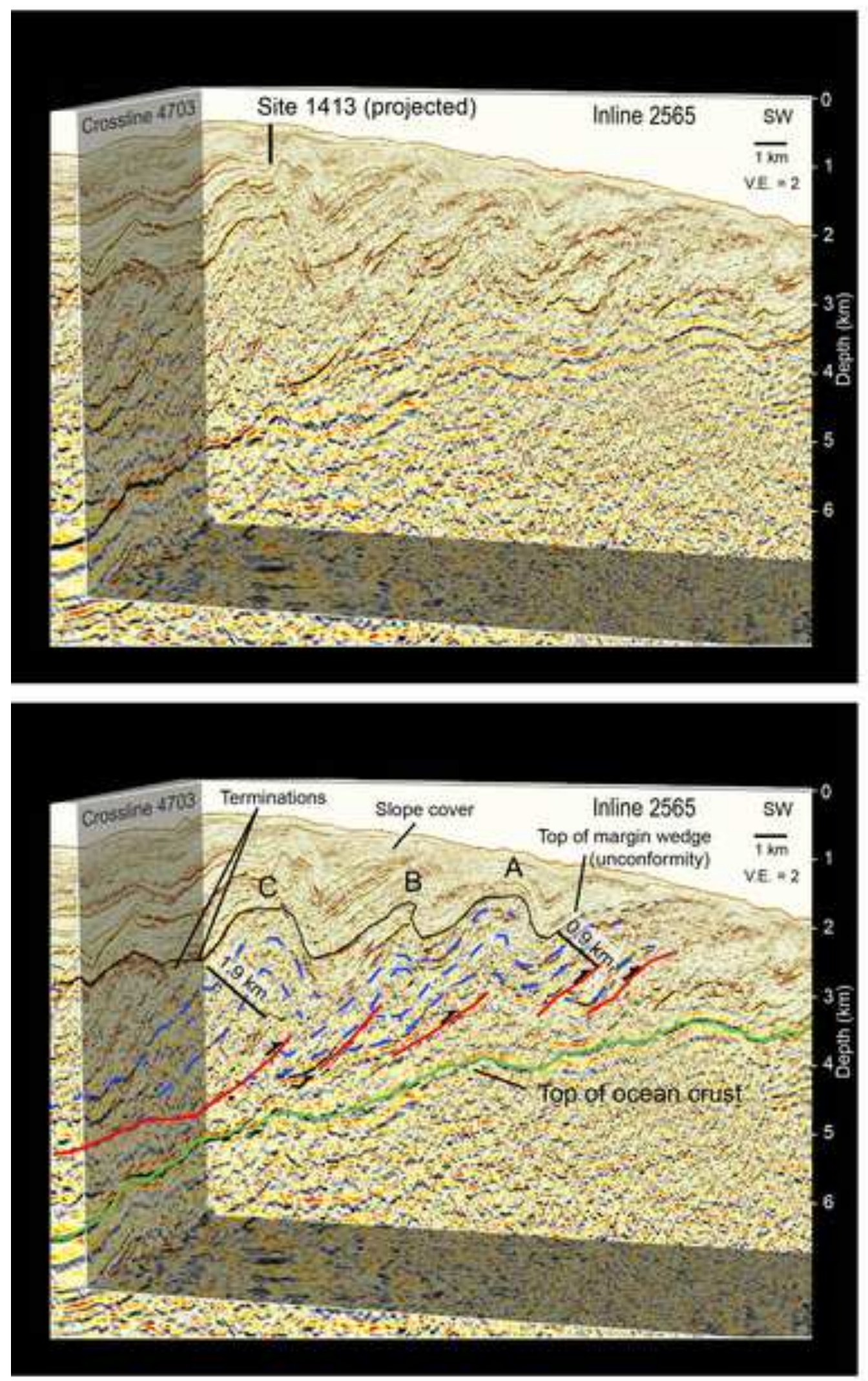

Figure 3 

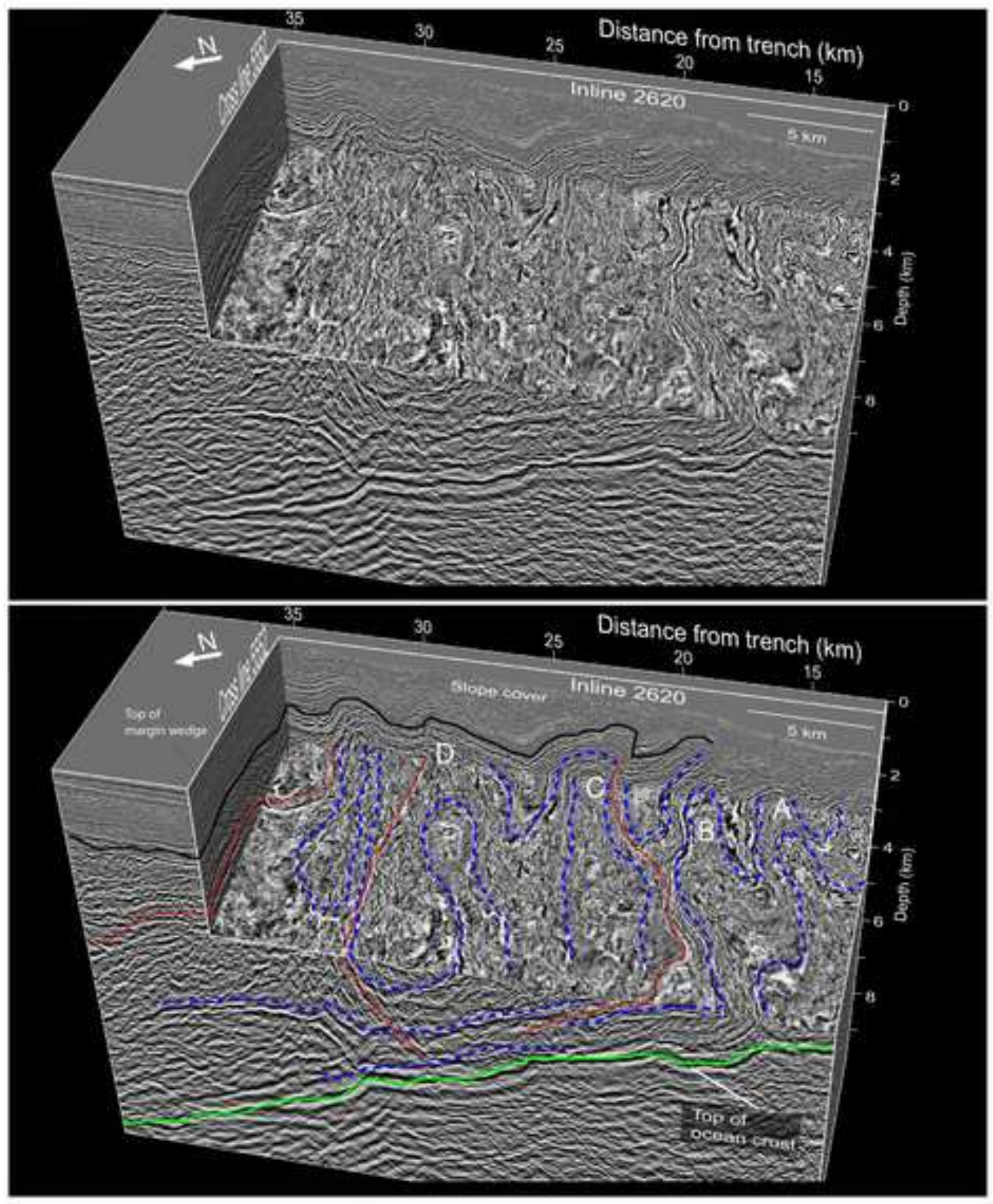

Figure 4 

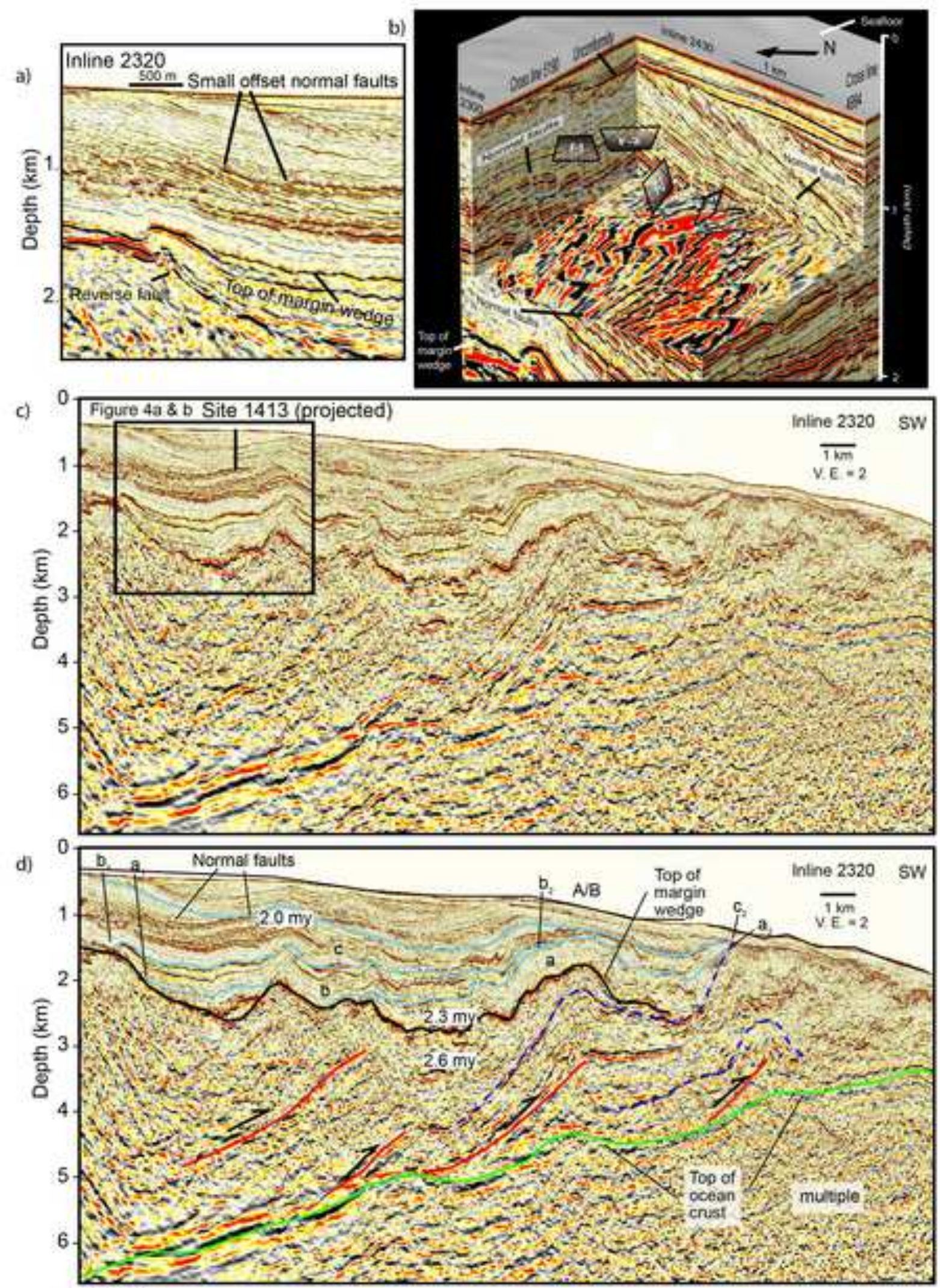

Figure 5 

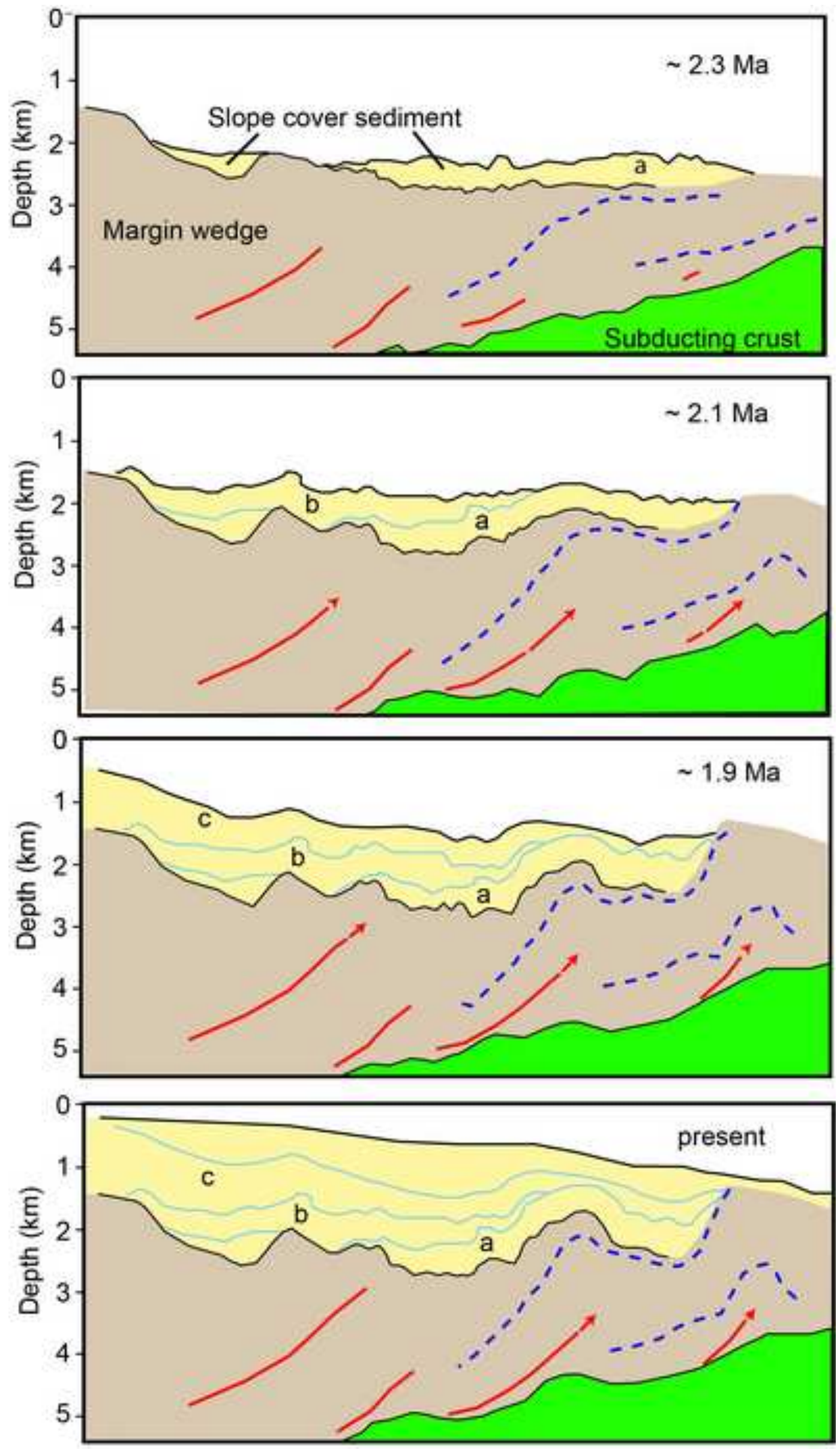

Figure 6 

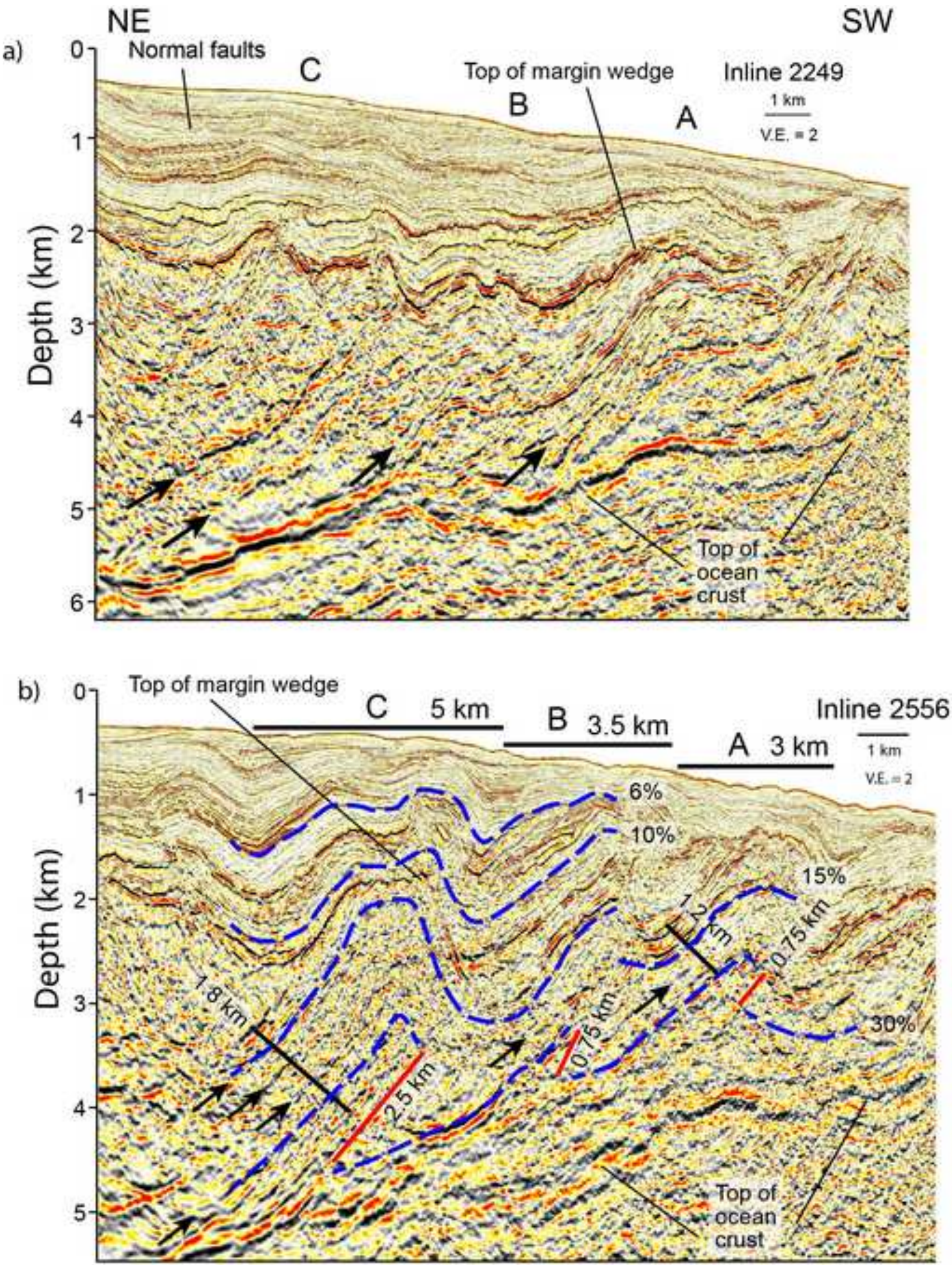

Figure 7 

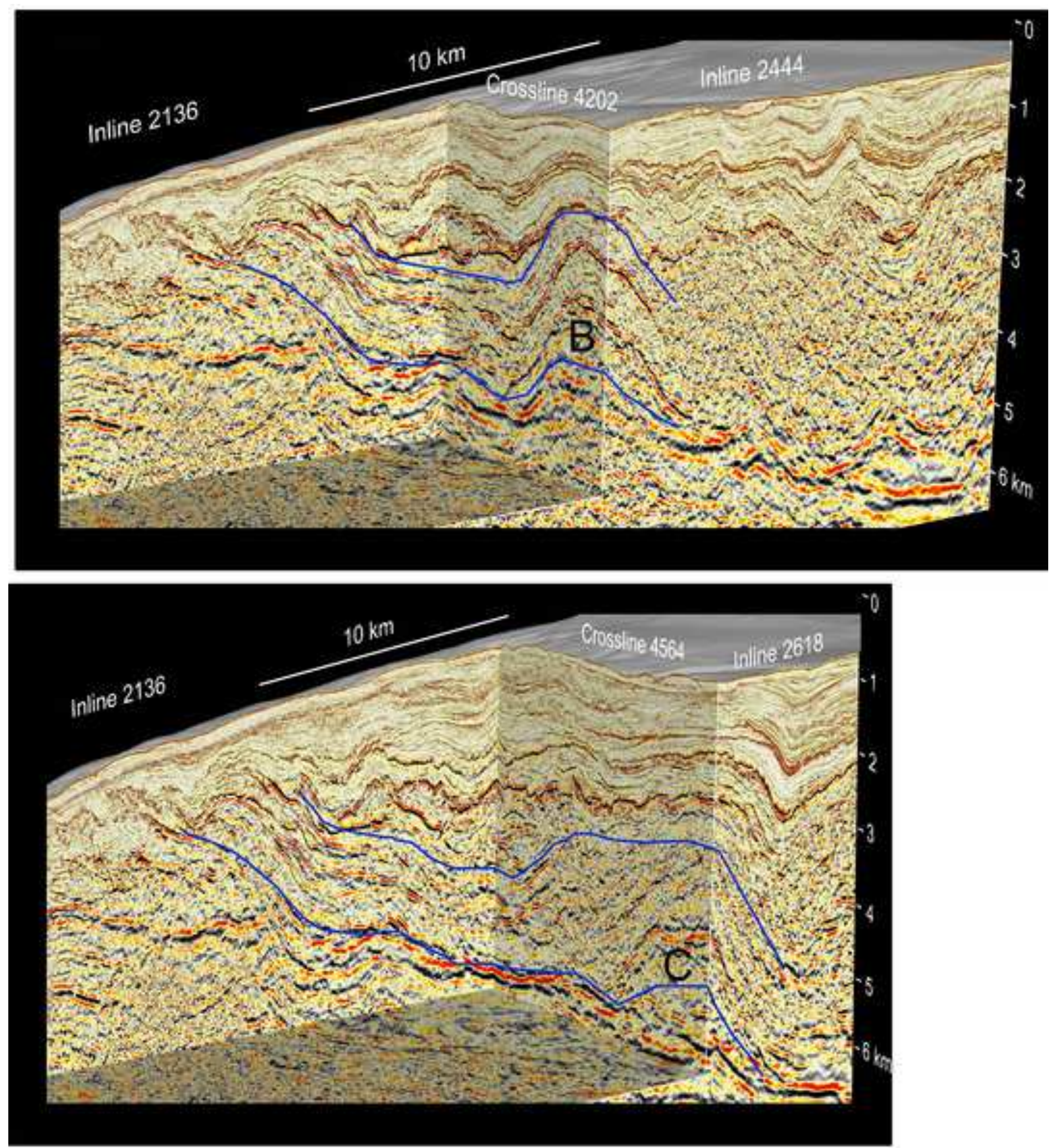

\section{Figure 8}



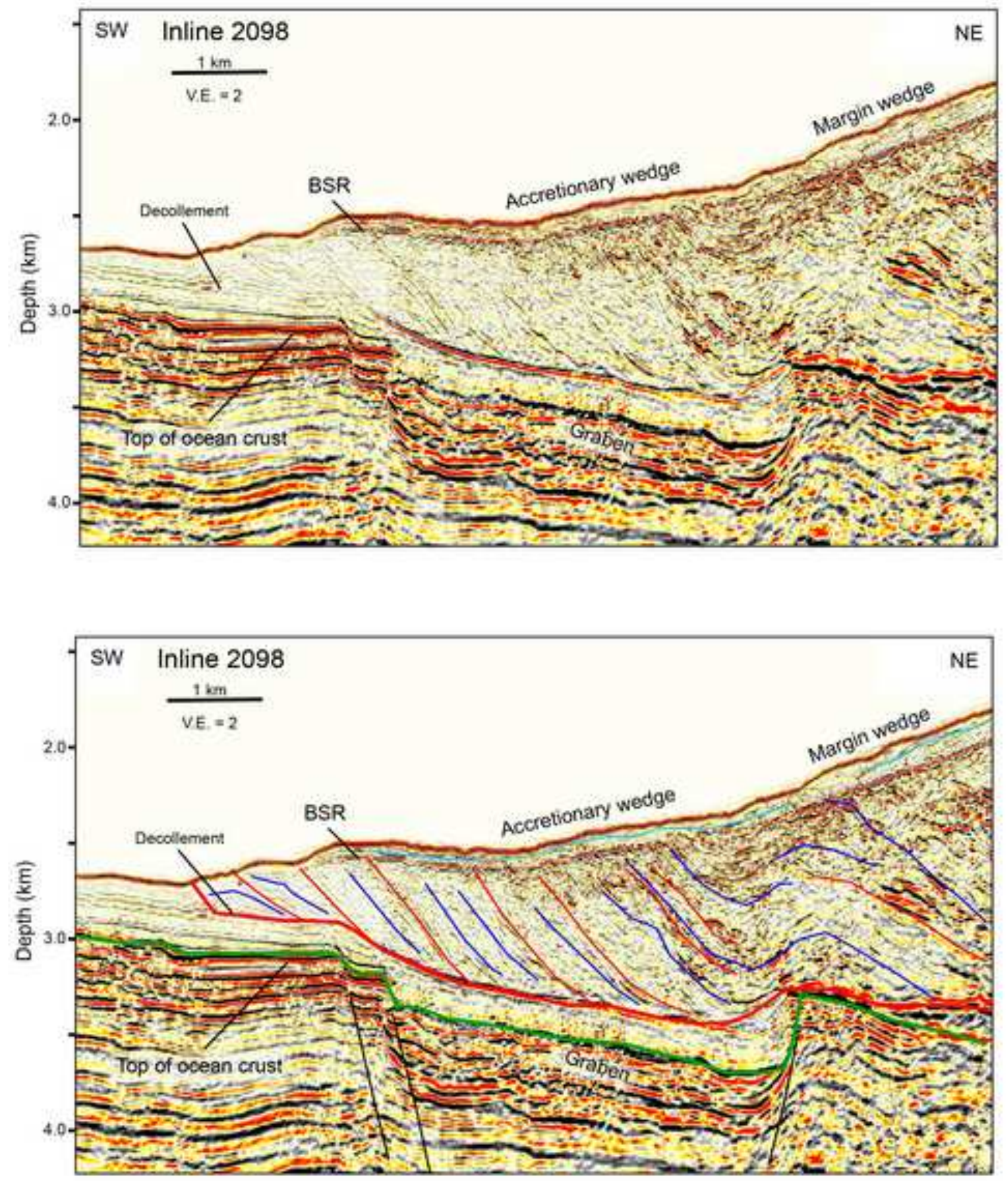

Figure 9 